\title{
Characterizing potential repelling volatiles for "push-pull" strategy against stem borer: a case study in Chilo auricilius
}

Xin $\mathrm{Yi}^{1,2}$ D, Song Shi ${ }^{1,2}$, Peidan Wang ${ }^{1,2}$, Yaoyao Chen ${ }^{1,2}$, Qiqi Lu ${ }^{1,2}$, Tianyi Wang ${ }^{3}$, Xiaofan Zhou ${ }^{4^{*}}$ and Guohua Zhong ${ }^{1,2^{*}}$

\begin{abstract}
Background: Massive techniques have been evaluated for developing different pest control methods to minimize fertilizer and pesticide inputs. As "push-pull" strategy utilizes generally non-toxic chemicals to manipulate behaviors of insects, such strategy is considered to be environmentally friendly. "Push-pull" strategy has been extraordinarily effective in controlling stem borers, and the identification of new "pushing" or "pull" components against stem borers could be significantly helpful.

Results: In this study, the results of field trapping assay and behavioral assay showed the larvae of C.auricilius, one kind of stem borers, could be deterred by rice plant under tilling stage, its main host crop. The profiles of volatiles were compared between rice plants under two different developmental stages, and a-pinene was identified as a key differential component. The repelling activity of a-pinene against C.auricilius was confirmed by Y-tube olfactometer. For illuminating the olfactory recognition mechanism, transcriptome analysis was carried out, and 13 chemosensory proteins (CSPS) were identified in larvae and 19 CSPS were identified in adult of C.auriciliu, which was reported for the first time in this insect. Among these identified CSPS, 4 CSPS were significantly regulated by a-pinene treatment, and CSP8 showed good binding affinity with a-pinene in vitro.

Conclusions: Overall, C.auricilius could be repelled by rice plant at tilling stage, and our results highlighted a-pinene as a key component in inducing repelling activity at this specific stage and confirmed the roles of some candidate chemosensory elements in this chemo-sensing process. The results in this study could provide valuable information for chemosensory mechanism of C.auricilius and for identification of "push" agent against rice stem borers.
\end{abstract}

Keywords: "Push-pull" strategy, Host plants, a-pinene, Olfactory

\section{Background}

Chemical control is considered as the most effective and efficient strategy against insect pests in agriculture [1]. However, after intensive pesticide applications, many health and environmental problems have become starkly apparent [2]. Seeking for alternative pest management strategies to reduce pesticide use and create more

\footnotetext{
*Correspondence: xiaofan_zhou@scau.edu.cn; guohuazhong@scau.edu.cn ${ }^{4}$ Guangdong Province Key Laboratory of Microbial Signals and Disease Control, Integrative Microbiology Research Centre, College of Agriculture, South China Agricultural University, Guangzhou, China

${ }^{1}$ Key Laboratory of Crop Integrated Pest Management in South China, Ministry of Agriculture, South China Agricultural University, Guangzhou, China

Full list of author information is available at the end of the article
}

environmentally sound production system has aroused worldwide attentions. One such alternative method is an ecological management approach named "push-pull strategy". By using push-pull strategy, insects are either deterred away from the main plant (push), or attracted (pull) to other areas by using stimuli that lure the insects [3]. Establishing such a system requires a comprehensive understanding of the associated chemical ecology of plant-insect, and such interactions between pests and plants are based on semiochemicals released by the plants [4]. These semiochemicals that repel pests from the main crop which is "push" component; or attract pests away from the main crop which is "pull" component [5].

(c) The Author(s). 2019 Open Access This article is distributed under the terms of the Creative Commons Attribution 4.0 International License (http://creativecommons.org/licenses/by/4.0/), which permits unrestricted use, distribution, and 
Rice is one of the most important food crops, and is a staple food for more than half of the global population [6]. Rice stem borers expose great threats to rice and some graminaceous plants, as shortly after the larvae hatch, they enter into the leaf sheath to the stem by boring and making tunnel inside the stem and filling by frass to damage the plants [7]. It is difficult to achieve effective control against stem borer due to the cryptic and nocturnal habit of the adult moth and the protection provided by the host stem at its immature stages [8]. Both on-station and onfarm trials have shown that the "push-pull" strategy is effective in controlling stem borers [9]. The identification of new behaviorally active compounds released by host and non-host plants will help develop "push-pull" control strategy. The incidence of Chilo auricilius, one kind of stem borers, was more frequent in paddy field which located near sugarcane crop as it could rely on sugarcane for the sustenance at certain developmental stage during its life cycle [10-12]. In such case, providing that the chemicals emitted from main host plant at certain stage were potentially maladaptive and intolerable to insect, a prerequisite for insect is to adapt to alternate host plants based on its innate ability or experience [13]. During this process, identification of the vital chemicals and illuminating the mechanism of repelling process would be helpful to provide effective "push" agents to establish "push-pull" strategy against C.auricilius and other closely related species of stem borers [14-16].

In this study, field trapping assay was carried out to examine the number of C.auricilius in field at different growth stages of rice, and the indoor behavioral responses to different host plants were also recorded. To explore the mechanism of such shift in host preference, the volatile profile of rice plant at tilling stage was compared with that at seedling stage, and $\alpha$-pinene was identified as a key differential compound. The repelling activity of $\alpha$-pinene against $C$.auricilius was further confirmed by Y-tube assay. For the perception mechanism of C.auricilius, the transcriptome analysis was carried out, 19 potential chemosensory proteins were identified from adult C.auricilius, and the differentially expressed chemosensory genes regulated by $\alpha$-pinene were identified, and eventually the binding affinity between $\alpha$ pinene and the identified chemosensory protein was measured by competitive binding assay in vitro. The results in this study highlighted $\alpha$-pinene as "push" component, and the mechanism of olfactory perception was also demonstrated to provide potential targets in pest management.

\section{Methods}

Insect

The larvae of C.auricilius were collected in Baiyun experimental field $\left(114^{\circ} 44^{\prime} \mathrm{N}, 23^{\circ} 39^{\prime} \mathrm{E}\right)$ of Guangdong academy of agricultural sciences and reared with artificial diet described previously [17]. They were maintained in an incubator until emergence (condition: under temperature of $26 \pm 1{ }^{\circ} \mathrm{C}$ photophase, relative humidity 70 $80 \%$ with 1:1 photoperiod). Adult moths were maintained under the same conditions with a supply of $10 \%$ sucrose solution.

\section{Field trapping}

To investigate the number of C.auricilius in sugarcane and paddy field at different developmental stages of rice plants, the field trapping assay was carried out in the Baiyun experimental field, Guangzhou, Guangdong of China from 4th Oct 2017 to 10th Nov 2017. First trial was conducted from 4th Oct 2017 to 10th Oct 2017. A trap device with a one-way entrance was used in the field trial. The cotton was dosed with $10 \%$ of the sucrose solution and placed inside of the trap device. The trap device was hung on the branch of rice and sugarcane crop, respectively. For each kind of crop, six trap devices were randomly placed. To eliminate the bias, the device was rotated every day to avoid uneven distribution of the insects in the field. The contents inside of the trap device were emptied every day, and each insect species was identified and the number of C.auricilius was counted and other species of insects were discarded. After 7 days, the total number of captured C.auricilius was calculated and the number of insects in each device was set as one replicate. And after 1 month, when the rice entered into the tilling stage (3rd Nov 2017 to 9th Nov 2017), the same procedure was conducted again.

\section{Behavioral experiments}

Behavioral experiments were performed using a glass Ytube olfactometer with a $20 \mathrm{~cm}$ truck length, $17 \mathrm{~cm}$ branch length with a $75^{\circ}$ angle at the Y-junction, drying column containing activated charcoal, water column containing distilled water, sample cylinder, air pump to push air through activated charcoal and distilled water, and SA751.5 sampling pump to collect odor from plants. A humidified continuous air flow was delivered at 200 $\mathrm{ml} / \mathrm{min}$. The experiment was carried out at $25 \pm 1{ }^{\circ} \mathrm{C}$, $60 \pm 5 \% \mathrm{RH}$, and under four 16-W cool white lights at the top to ensure even distribution of light. The rice plant and the sugarcane plant under stem elongation stage were introduced into sample cylinder after removed the mud, respectively. One insect for one time was released into the Y-tube at the entrance of the stem with maximum observation duration of $10 \mathrm{~min}$ per responder. The choice was recorded when the insect entered into one specific arm for at least $5 \mathrm{~cm}$. Twenty insects were used in one assay, and repeated for three times. 


\section{Headspace collection of plant volatiles}

Prior to volatile collection, the root of plant was carefully covered by wet absorbent cotton. The collection method was followed by Silva. et al. described previously [18]. The plant samples (the rice plant under seedling and tilling stage) were placed in a $30 \mathrm{~L}$ glass jar and were left for $30 \mathrm{~min}$ for acclimatization prior to volatile collection. Then, a stream of charcoal filtered air was passed over the plant for $2 \mathrm{~h}$ at a flow rate of $20 \mathrm{~mL} \mathrm{~min}^{-1}$, and volatile collection was conducted by passing the air stream for $10 \mathrm{~h}$ by using $200 \mathrm{mg}$ Tenax TA (60/80 mesh; CAMSCO, Houston, TX, USA). The samples were analyzed by gas chromatograph (GC) coupled to a mass spectrometer (MS) from Agilent Technology Inc. The collected volatiles were released from the Tenax TA thermally at $250^{\circ} \mathrm{C}$ for $5 \mathrm{~min}$. During experiment, splitless mode was used with analytical column of HP- $5 \mathrm{~ms}$ $5 \%$ Phenyl Methyl Siloxane $(30 \mathrm{~m} \times 0.25 \mathrm{~mm})$ with array detection from 35 to $350 \mathrm{amu}$ (total scan). The temperature for the transfer line was $280^{\circ} \mathrm{C}$, and the ionization energy was $70 \mathrm{eV}$. Helium was used as a carrier gas at a flow rate of $1.0 \mathrm{~mL} / \mathrm{min}$. For each treatment, three replicates were performed, and the identification process was repeated for three times to improve accuracy.

\section{Behavioral responses to a-pinene}

The assay was carried out as previously described with little modification. Y-tube was connected to drying column containing activated charcoal, water column containing distilled water, sample bottle instead of cylinder, air pump to push air through activated charcoal and distilled water. For two sample bottles, one bottle contained $300 \mu \mathrm{L} \alpha$-pinene which was diluted to $1 / 10(v / v)$ with acetone prior to assay, whereas the other one contained $300 \mu \mathrm{L}$ acetone and served as control. The recording process was carried out as previously described, and the preference index values were based on four replicates. Each replicate contained 20 larvae (3rd and 4th instar).

\section{Rice sample collection and expression level examinations of terpene synthases genes (TPSs)}

For each sample, $50 \mathrm{mg}$ rice leaves were isolated from rice plants at tilling stage and seedling stage, respectively. The samples were collected at the same time and were store at $-80^{\circ} \mathrm{C}$ before RNA extraction. Total RNA was extracted from rice plants using Trizol following the instruction of Eastep ${ }^{\circ}$ Super (Promega). The concentration of isolated RNA was measured by Nanodrop (Thermo Fisher Scientific, USA). For each sample, one $\mu \mathrm{g}$ of the isolated RNA was reversely transcribed to the first-strand cDNA by M-MLV reverse transcriptase (TaKaRa, China) and oligo $(\mathrm{dT})_{18}$ as primer at $42^{\circ} \mathrm{C}$ for $60 \mathrm{~min}$. The expression patterns of potential TPSs were investigated by quantitative real-time PCR (qRT-PCR), following the protocol described previously [19].The quantitative PCR was performed using the iCycleriQ Real-Time PCR Detection System (Bio-Rad) with SYBR green dye (Taraka, China) binding to double-strand DNA at the end of each elongation cycle. The sequences of TPSs were isolated in "The rice annotation project database", and the primers were designed and listed in the Additional file 1: Table S1, and tubulin was used as reference gene. All amplifications were performed with three biological and three technical replicates. Relative gene expression data were analyzed using the $2-\Delta \Delta C T$ method as described by Livak [20].

\section{Illumina sequencing}

The larvae of C.auricilius at different developmental stages were mixed together and adults (5th day after emergence) were also collected. For each sample, the amount was $5 \mathrm{~g}$, and repeated for three times. Total RNA was extracted by the RNA isolation kit (Omega, USA) according to the manufacturer's instructions. The concentration of isolated RNAs was measured by Nanodrop (Thermo Fisher Scientific, USA). The procedure of cDNA library construction was conducted following the description in our previous study [21]. mRNA was purified by oligo (dT) and was then split into small fragments. The first strand of cDNA was synthesized by using a random primer and mRNA as template. Then, we used buffer for reverse transcriptase, dNTPs, RNase $\mathrm{H}$ and DNA polymerase I for double-strand cDNA, and the obtained cDNA was purified for end repair and poly (A) addition. Finally, the $5^{\prime}$ and $3^{\prime}$ ends of the fragments were ligated. Suitable fragments, examined by agarose gel electrophoresis, were selected as templates for PCR amplification to create a cDNA library. The cDNA library was sequenced on an Illumina sequencing platform (HiSeqTM 2000) and $100 \mathrm{bp}$ paired-end reads were generated.

\section{Identification of chemosensory genes}

CSP genes from larvae and adult of C.auricilius were identified from the de novo transcriptome assembly, respectively, and the identification process was followed as previously described [19]. TransDecoder v2.0.0 was used to annotate the coding regions in the transcriptome assembly, and the InterProScan v5 was used to check for the presence of the characteristic domain of CSPs (IPR005055) of the translated protein sequences. The TBLASTN was performed by using the identified protein sequences of CSPs as queries to identify putative CSP coding regions. Then GeneWise v2.2.0 was used to perform homology-based gene prediction by using the most similar query sequence as reference. Then all the predicted genes were further examined for the presence of the characteristic CSP domain in their translated protein sequences. A phylogenetic tree was constructed by 
MEGA5.0 and by maximum likelihood method. The identified CSPs in C.auricilius were named after orthologous genes in Bombyx mori [22].

\section{Examination of expression levels of candidate CSPs}

$\alpha$-pinene ( $\geq 99 \%)$ was commercially purchased from $J \& \mathrm{~K}^{\circ}$ (China) under CAS number of 7785-70-8. For the insect treatment, two sets of artificial diets were provided, and one set of diet was incorporated with $1.50 \mathrm{mg} / \mathrm{ml} \alpha$ pinene. Another set of diet was added by acetone alone and considered as control. After $12 \mathrm{~h}$ starvation, two groups of 3rd instar larvae of C.auricilius were fed by different sets of diets, respectively. For each group, there are 15 insects, and was repeated for three times. After $24 \mathrm{~h}$, all insects were collected and anesthetized. Then the insects were dissected and stored at $-80^{\circ} \mathrm{C}$ before RNA extraction. The total mRNA extraction and qRTPCR was conducted as described previously by using primers listed in Additional file 2: Table S2. All amplifications were performed with three biological replicates.

\section{Expression and purification for candidate CSPs}

The gene-specific primers of CSP8 were designed with restriction enzyme sites and protection base attaching to the $5^{\prime}$ end (forward: 5'-TTATTCTGGGAYGACGAY GCCGT-3', reverse: 5'-CGCCATGGGAAGATGAAA AGTACCCTAGC-3'). The full-length coding sequence (CDS) of CSP8 was amplified by ExTaq DNA polymerase (TaKaRa, Japan) and was then connected to pET32a (Invitrogen, US) by T4 DNA ligase (Takara, China) at $14{ }^{\circ} \mathrm{C}$. The product of connection was translated into pET-32a, and cultivated at $37^{\circ} \mathrm{C}$ for $14-16 \mathrm{~h}$. The positive clone was identified by PCR, and after Isopropyl-Dthiogalactoside (IPTG) $(1 \mathrm{mmol} / \mathrm{L})$ was added, those positive bacterial colonies were inoculated overnight until its $\mathrm{OD}_{600}$ reached 0.4-0.6. The inoculated products were broken by sonic oscillator, and were examined by SDS-PAGE. The recombinant protein was purified by affinity chromatography using HisTrap columns prepacked with Ni Sepharose (GE Healthcare) as previously described [19]. The cultures were harvested by centrifugation and lysed with solution $(10 \mathrm{mM}$ imidazole, 300 $\mathrm{mM} \mathrm{NaCl}$ and $50 \mathrm{mM} \mathrm{NaH2PO} 4)$. The protein solution was washed and balanced by binding buffer in the kit (20 mM NaH2PO4, $500 \mathrm{mMNaCl}, \mathrm{pH}$ 7.8) to make sure the sample adhere to the column completely after filled the filtered solution into the column. Then, a linear gradient concentration of imidazole was used to elute the recombinant protein adhered on the column, and then purified protein was dialyzed by Tris-HCL $(\mathrm{pH}=7.4)$. His-tag was removed by incubating in Bovine Enterokinase overnight. The purified protein was collected and examined by $12 \%$ SDS-PAGE. Bradford method was used to determine protein concentration [23].

\section{Fluorescence-based ligand binding assays}

The binding affinity was measured in a $1 \mathrm{~cm}$ light path quartz cuvette by JASCO J-715 CD spectrophotometer (HITACHI) at room temperature. N-phenyl-1-naphthylamine (1-NPN) was used as the fluorescent probe, and all the chemicals used in the measurement were dissolved in HPLC purity grade methanol. Before measurement of binding affinity, the intrinsic florescence was examined by using protein solution in Tris- $\mathrm{HCl}$ buffer with different concentrations of $1-\mathrm{NPN}(0,2,4,8,12,16$ and $20 \mu \mathrm{M})$. The binding affinity between CSP8 and 1-NPN was measured by recording the excitation wavelength of $2 \mu \mathrm{M} 1$ NPN in $50 \mathrm{mM}$ Tris- $\mathrm{HCl}$ at $337 \mathrm{~nm}$ and emission spectra between $350 \mathrm{~nm}$ and $550 \mathrm{~nm}$. After that, $2 \mu \mathrm{M}$ of CSP8 protein was added into the solution and titrated with aliquots of $1 \mathrm{mM} 1-\mathrm{NPN}$ to final concentrations of 2 to $16 \mu \mathrm{M}$. The affinity between $\alpha$-terpene and CSP8 were measured by competitive binding assays in presence of both protein solution and 1-NPN by adding different concentrations of $\alpha$-terpene ( 0 to $20 \mu \mathrm{M}$ ). For each measurement, we performed three replicates. The maximum value of fluorescence emission was plotted against the concentration of $\alpha$-terpene, and the curves were linearized by Scatchard plots. The dissociation constants of the competitors were calculated as described previously by using the corresponding $\mathrm{IC}_{50}$ values according to the equation: $\mathrm{KD}=\left[\mathrm{IC}_{50}\right] /\left(1+[1-\mathrm{NPN}] / \mathrm{K}_{1-\mathrm{NPN}}\right)$, where $[1-\mathrm{NPN}]$ is the free concentration of $1-\mathrm{NPN}$ and $\mathrm{K}_{1-\mathrm{NPN}}$ is the dissociation constant of the protein complex/1-NPN [24].

\section{Results}

\section{Field trapping}

Other than C.auricilius, there were many other species and they were discarded. A total of $367 \pm 108$ C.auricilius were captured for 7 days when the trap device was placed in the paddy field and the rice was under the seedling stage. And the number of captured insects at paddy field showed significant difference $(P<0.0001)$ compared with the number captured in sugarcane filed (78 \pm 35$)$ (Fig. 1a). After 30 days, when the rice plant entered into the tilling stage, the trapping assay was conducted at the same condition. However, the situation was different as 1 month ago. As the number of captured C.auricilius in paddy field $(98 \pm 36)$ was much less than the number in sugarcane field (278 \pm 97$)$ (Fig. 1b).

\section{Behavioral responses}

The preference of C.auricilius larvae to rice plant was compared with that to sugarcane plant by using Y-tube olfactometer. The results indicated that Cauricilius larvae preferred rice plant under seedling stage to sugarcane plant under stem elongation stage (3rd instar larvae, $\chi^{2}=18.2, P<0.0001$, 4th instar larvae, $\chi^{2}=33.46$, $P<0.0001 ;$ 5th instar larvae, $X^{2}=7.219, P=0.0072$, 

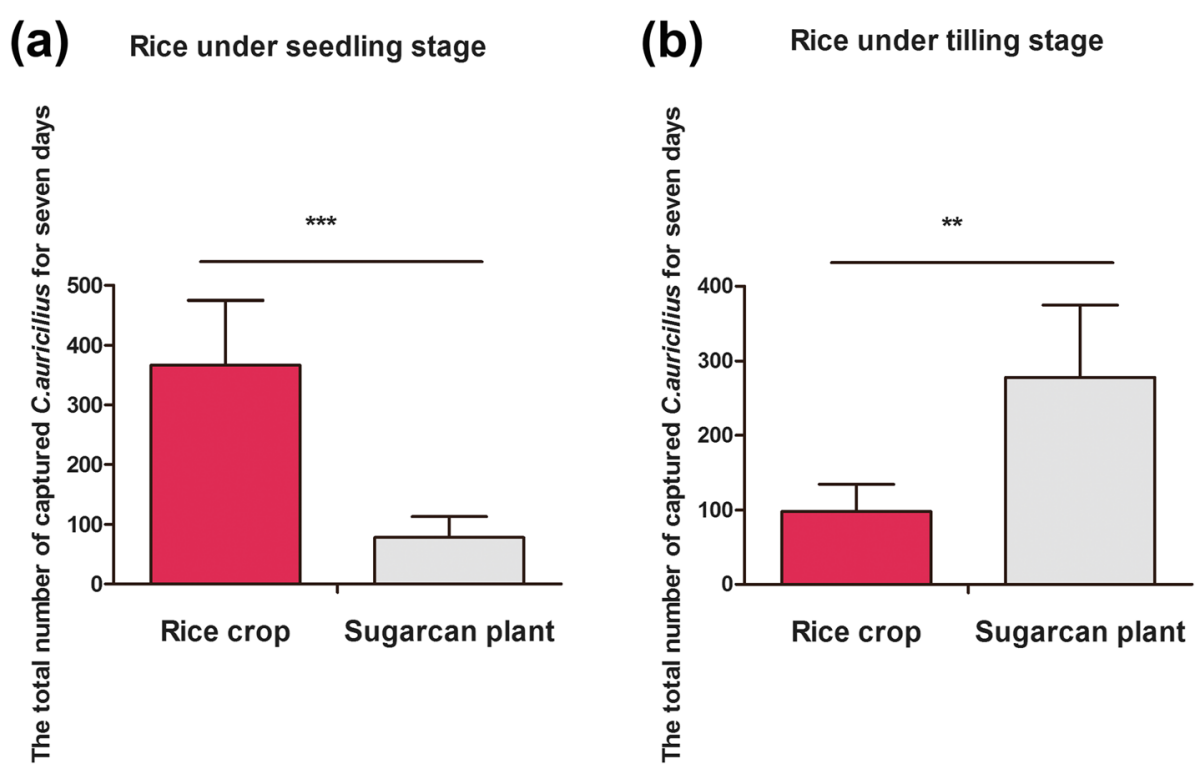

Fig. 1 The total number of trapped C.auricilius for 1 week at sugarcane or paddy field. The experiment was conducted from 4th Oct to 10th Oct (a) and from 3rd Nov to 9th Nov (b), 2017 at Baiyun experimental field, Guangzhou, Guangdong, China. a The number of trapped insects in paddy field when the rice was under seedling stage compared with the number in sugarcane field (the sugarcane was under stem elongation stage). $\mathbf{b}$ The number of trapped insects in paddy field when the rice was under tilling stage compared with the number in sugarcane field (the sugarcane was under stem elongation stage). The number of insects in one device was served as one replicate, and there are six trapping devices in each crop field. ( $t$ test; **: $P<0.001,{ }^{* *}: P<0.01 ;{ }^{*}, P<0.05$; ns, not significant)

$6^{\text {th }}$ instar larvae, $X^{2}=10.34, P=0.0013$ ) (Fig. 2a). However, the preference of C.auricilius larvae changed when the rice entered into tilling stage. The C.auricilius larvae preferred volatiles from sugarcane to rice under tilling stage (3rd instar larvae, $X^{2}=14.6, P=0.0001$; 4th instar larvae, $\chi^{2}=9.32, P=0.0023$; 5th instar larvae, $\chi^{2}=8.139$, $P=0.0043 ;$ 6th instar larvae, $X^{2}=7.342, \quad P=0.0067$ ) (Fig. 2b).

\section{Volatile profiles of rice plants under two different stages} Eighteen compounds, including alcohols, ester, and alkane were identified from rice plant. And statistically significant differences could be observed in the concentrations of the identified volatile chemicals between the seedling and tilling stage, including linalool, tetradecane, tetradecyl vinyl ester, hexacontanoic acid, 1-4-methyl-benzene, epicedrol, pentadecane, $\alpha$-pinene, cis-9-hexadecenal, $(Z)-\quad 9-$ octadecenamide, and $1 \mathrm{H}$-indole (Table 1). Among the rice volatiles, pentadecane was the most abundant compound at seedling stage, while the amount of $\alpha$-pinene was the highest compared with other volatiles at the stage of tilling. As $\alpha$-pinene was reported to be as an effective repellent to insects, the following work would focus on this chemical.

\section{Behavioral response to a-pinene}

Then the Y-tube olfactometer was used to examine the behavioral response of C.auricilius to $\alpha$-pinene. Based on previous observation, the 1st and 2nd instar larvae showed relatively weak mobility, therefore, 3rd and 4th instar larvae were served as testing candidates for this experiment. The results showed that the 3rd and 4th instar larvae preferred to choose the solvent arm relative to $\alpha$-pinene arm, and the preference index to solvent exhibited significant difference comparing that to $\alpha$ pinene (3rd instar larvae, $X^{2}=16.06, P<0.0001$; 4th instar larvae, $\chi^{2}=15.02, P=0.0001$ ) (Fig. 3).

\section{Expression pattern of TPSs}

The expression patterns of TPS genes in rice plants under seedling and tilling stages were examined, respectively. Results showed that ten out of thirty genes exhibited significant differences between these two different growth phases. Among them, TPS2, TPS14, TPS22, and TPS23 exhibited extremely distinct differences between these two stages $(P<0.001)$ (Additional file 3: Figure S1), and these genes at tilling stage expressed 19.99, 238.75, 11.25, and 5.46 fold higher than the levels at the seedling stage, respectively. All the differentially expressed TPS genes showed higher expression levels at the stage of tilling comparing with the expression levels at seedling stage.

\section{Identification of CSPs from C.auricilius}

By analyzing the transcriptome assembly of C.auricilius, we identified 19 non-redundant CSP coding transcripts from adult moths (Datasheet S1, Fig. 4), which covered 
(a)

Sugarcane plant under stem elongation stage

Rice plant under seedling stage

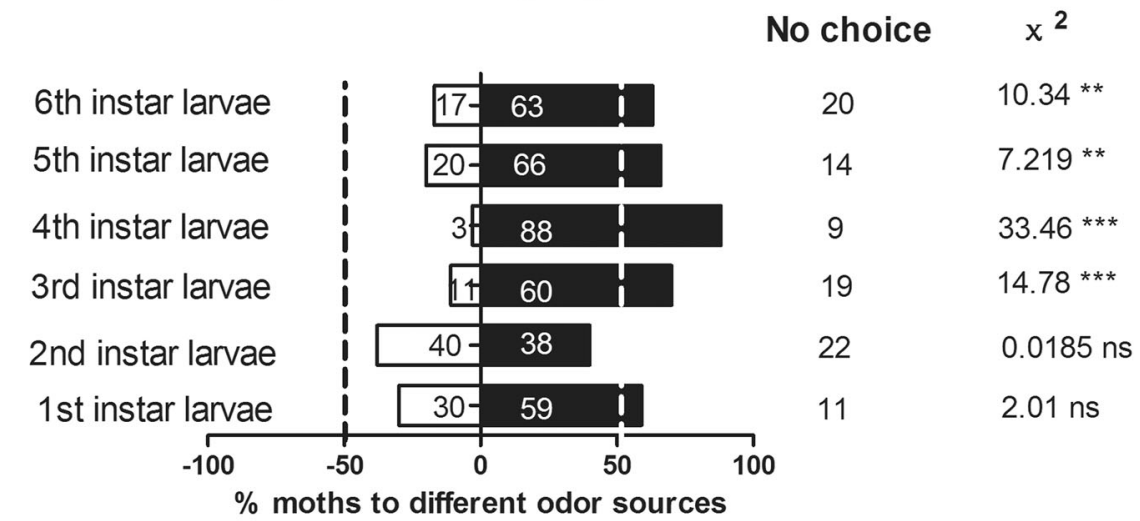

(b)

$\square$ Sugarcane plant under stem elongation stage

Rice plant under tilling stage

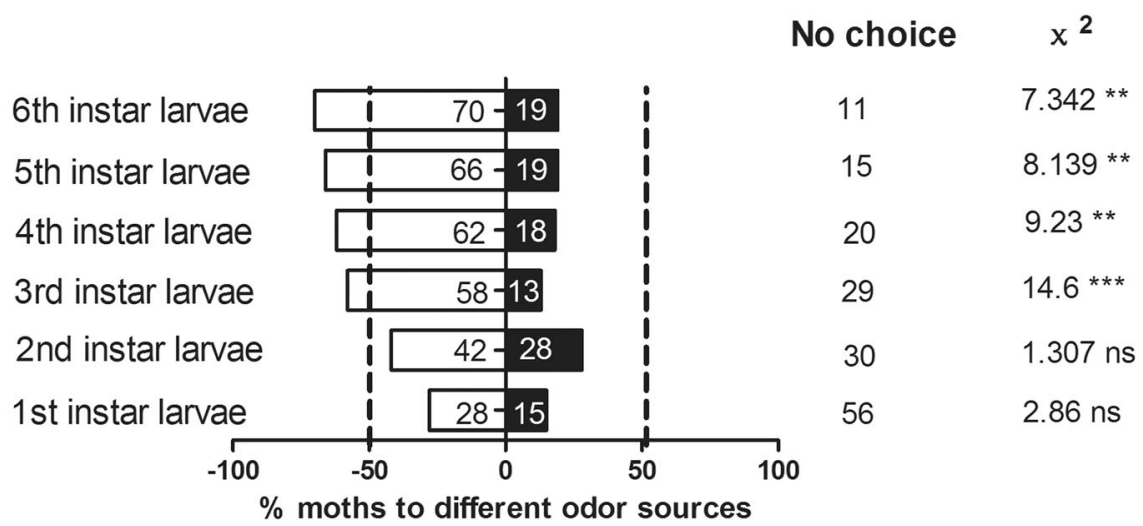

Fig. 2 Behavioral responses of C.auricilius larvae to rice and sugarcane plants at different stages measured by Y-tube olfactometer. Bar represented the overall percentages of moths choosing either of the host plants (\% moths to different odor sources = the number of moths choosing either arm / the total number of testing moths* 100\%), numbers in bracket indicated the total number of moths choosing the arm. a The number of C.auricilius larvae choosing either sugarcane plant (under stem elongation stage) or rice plant (under seedling stage); $\mathbf{b}$ The number of C.auricilius larvae choosing either sugarcane plant (under stem elongation stage) or rice plant (under tilling stage). (chi-squared test; ***: $P<0.001,{ }^{* *}: P<0.01 ;{ }^{*}, P<0.05$; ns, not significant). No choice indicated the moth did not make choice to enter into any arm within 10 min

all the CSPs expressed at larvae stage. Among these identified CSPS in adult, six CSPS (CSP2, CSP4, CSP6, CSP10, CSP13, and CSP18) were not present in larvae transcriptome. The identified CSPs were named after the CSPs from Bombyx mori [22]. To compare the CSPS expressed in C.auricilius with that in other closely related insect species, the phylogenetic analysis was performed by using previously reported CSPS in C. suppressalis [25], B.mori [22], Scirpophaga incertulas [26], Sesamia inferens [27]. Phylogenetic analysis showed that all the 92 CSPS from the five insect species revealed well-supported clades displaying clear orthologous relationships.

\section{Expression variations of candidate CSPs after treated by a-pinene}

After treated by $\alpha$-pinene, the expression variations of CSPs in C.auricilius larvae in response to $\alpha$-pinene were examined, the results showed that only 4 out of 13 CSPS exhibited significant differences in expression levels. And among these four significantly regulated CSPs, the expression levels of CSP5, CSP8, CSP9, and CSP13 were regulated by $1.67,3.95,1.54$, and 2.49 folds after treated by $\alpha$-pinene compared with control (Fig. 5). Among these differentially expressed CSPS, CSP8 was selected for further study as it is the only one up-regulated CSP after $\alpha$-pinene treatment. 
Table 1 Major volatile compounds identified by GC-MS in rice plants under seedling and tilling stages

\begin{tabular}{|c|c|c|c|}
\hline \multirow[t]{2}{*}{ Compound } & \multirow{2}{*}{$\begin{array}{l}\text { Retention } \\
\text { time } \\
\text { (min) }\end{array}$} & \multicolumn{2}{|l|}{ Relative area (\%) } \\
\hline & & Seedling stage & Tilling stage \\
\hline D-Limonene & 9.9777 & $0.45 \pm 0.26$ & ND \\
\hline Ethylhexonol & 10.1103 & $1.63 \pm 0.22$ & $N D * * *$ \\
\hline Undecane & 12.1686 & $0.67 \pm 0.14$ & $0.22 \pm 0.12$ \\
\hline Tridecane & 17.9126 & $0.92 \pm 0.33$ & $0.17 \pm 0.24$ \\
\hline Butyl dodecyl ester & 19.7798 & ND & $0.19 \pm 0.12$ \\
\hline Tetradecane & 20.5452 & $2.43 \pm 0.14$ & $0.32 \pm 0.14 * * *$ \\
\hline Tetradecyl vinyl ester & 20.7863 & $1.60 \pm 0.64$ & $0.37 \pm 0.18^{* * *}$ \\
\hline Hexacontanoic acid & 21.2406 & $0.93 \pm 0.78$ & $N D *$ \\
\hline 1-4-methyl- Benzene & 22.6543 & $1.66 \pm 0.92$ & $0.23 \pm 0.42 * * *$ \\
\hline Epicedrol & 22.7757 & $1.44 \pm 0.29$ & $N D * * *$ \\
\hline Pentadecane & 23.0311 & $3.13 \pm 0.93$ & $0.32 \pm 0.14^{* * *}$ \\
\hline a-Pinene & 23.6902 & ND & $1.37 \pm 0.68^{* * *}$ \\
\hline cis-9-Hexadecenal & 25.6299 & $1.63 \pm 0.26$ & $N D$ *** \\
\hline Tridec-2-ynyl ester & 25.9072 & ND & $0.34 \pm 0.14$ \\
\hline 2-Hexyl-1-dodecanol & 29.8717 & $0.84 \pm 0.31$ & ND \\
\hline 3,4-Dihydroxyphenylglycol & 36.3869 & ND & $0.10 \pm 0.01$ \\
\hline (Z)- 9-Octadecenamide & 38.5483 & $2.27 \pm 0.12$ & $N D * * *$ \\
\hline 1H-Indole & 39.0174 & $0.14 \pm 0.05$ & $N D * *$ \\
\hline Total contents & & $20.29 \pm 5.13$ & $3.63 \pm 2.19$ \\
\hline
\end{tabular}

ND Not detected, the data of the relative area in the table represent the mean values \pm S.E.M of three examinations. Different letters indicate significant difference of the expression levels $\left({ }^{* * *}: P<0.001,{ }^{* *}: P<0.01 ;{ }^{*}, P<0.05\right.$, two-way ANOVA)

\section{Fluorescence binding assays}

The CSP8 recombinant protein was induced and expressed successfully, the purified protein showed a single band with molecular weight of $18 \mathrm{kDa}$ by SDSPAGE (Fig. 6a). After the His-tag was removed successfully, the concentration for this purified solution used for further study was $5.7 \mathrm{mg} / \mathrm{mL}$. To examine the intrinsic fluorescence, 1-NPN was added into the protein solution to make its concentration reach to $0,2,8,12$, $20 \mu \mathrm{M}$, respectively. With the increasing concentrations of 1-NPN, the intensity of fluorescence decreased from 1212 to $853,643,400$, and 219 , respectively, which indicated that 1-NPN could bind to the protein to induce fluorescence quenching. By titrating $4 \mu \mathrm{M}$ CSP8 with increasing concentrations of $1-\mathrm{NPN}$, a saturation and linear Scatchard plot were observed (Fig. 6b\&c), which indicated that CSP could bind to 1-NPN with a dissociation constant of $3.995 \pm 0.13 \mu \mathrm{M}$, which suggested 1NPN could be used as probe to examine the binding affinity of CSP8 to ligand. Then, 1-NPN was used as the probe to measure the binding affinity of CSP8 to $\alpha$ pinene in competitive binding assay, and the results indicated that CSP8 showed high affinity for $\alpha$-pinene with 11.16 of $\mathrm{IC}_{50}$ values (the concentration of the ligand that yielded $50 \%$ of the initial fluorescence value) and 4.34 of binding constant (Fig. 6d).

\section{Discussion}

The indoor results of behavioral responses demonstrated that the pattern of preference of C.auricilius was nicely matched the situations recorded in the field. The olfactometer system, a sealed device with channels, enabled the candidate insect move freely and decide between channels permeated with the tested odor or with solve [28]. During this testing process, only the olfactory

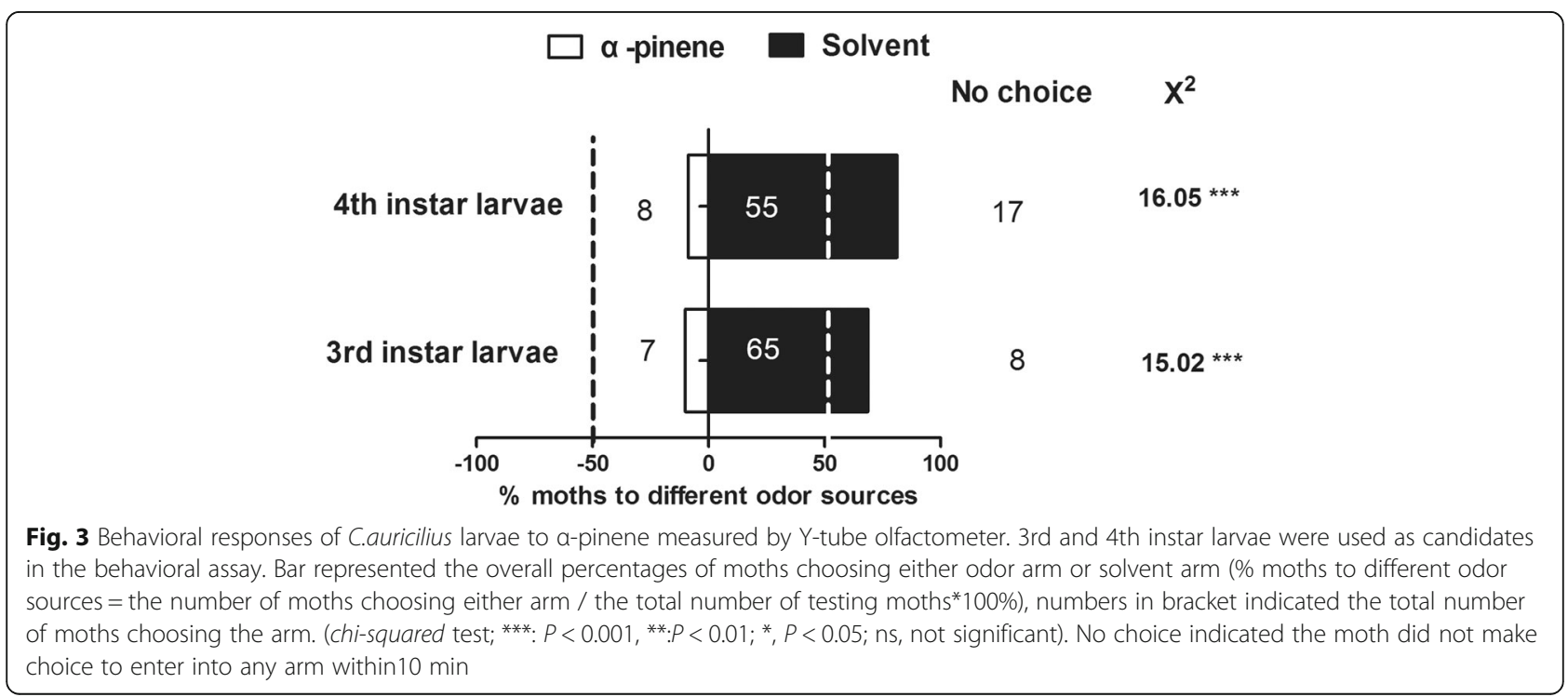


Tree scale: 1

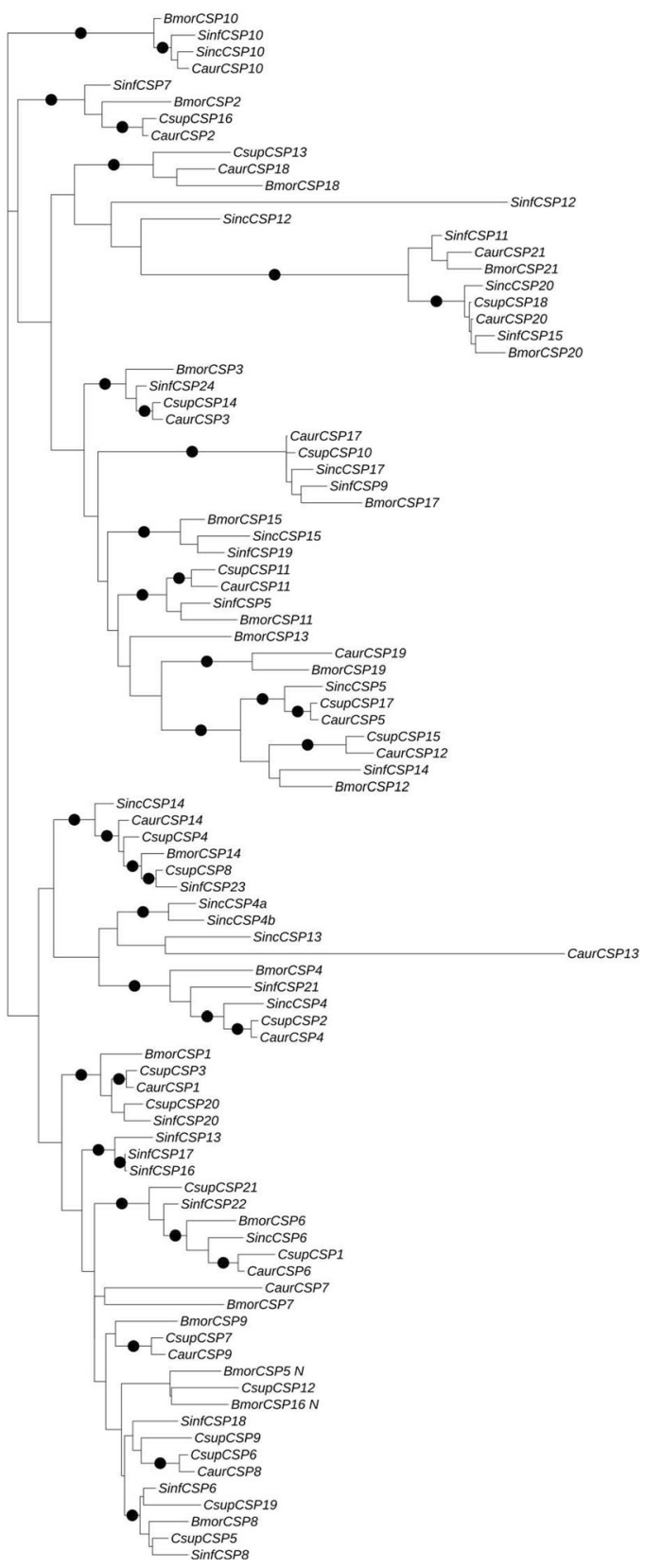

Fig. 4 Phylogenetic analysis of CSPS in five Lepidopera insects. The phylogenetic tree was constructed by MEGA 5.0. Bootstrap values $\geq 90 \%$ (1000 replicates) were indicated as black dot at the nodes. CSPs from C.auricilius identified in this study were indicated as CaurCSPs. The CsupCSP, BmorCSP, SinfCSP and SincCSPs represented the CSPs identified from C. suppressalis, B.mori, Scirpophaga incertulas, and Sesamia inferens from previous studies $[22,25-27]$

recognition was considered. Volatiles from host plants are important for insects to choose suitable sites, and differences in the types and concentrations from volatile components could directly influence the host discrimination $[29,30]$, the mating process [31], and reproduction of insects [32, 33]. Based on our results, we 


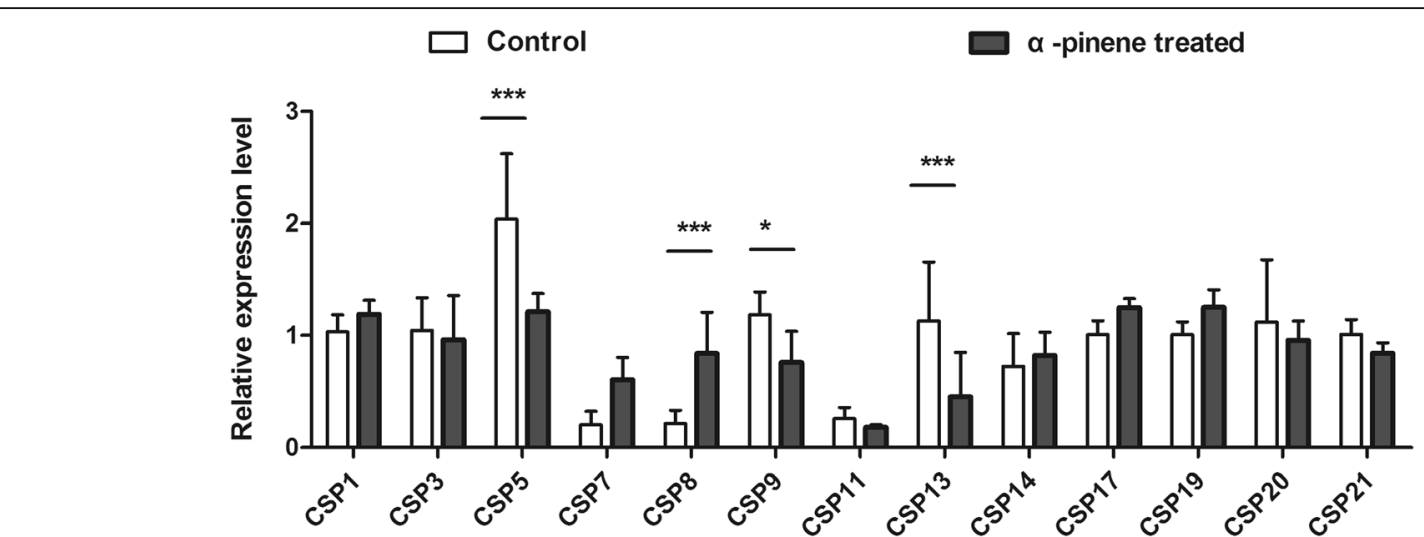

Fig. 5 Expression levels of identified CSPS in 3rd instar larvae of C.auricilius in response to a-pinene treatments. The data represented the mean values \pm S.E.M of three replicates (**: $P<0.001,{ }^{* *}: P<0.01 ;{ }^{*}, P<0.05$, two-way ANOVA)

suggested that the preference shift of C.auricilius at specific stage could be at least partly due to the unpleasant odors emitted by rice plant at certain stage [34]. The ability to detect and discriminate toxic or unpleasant odor is essential because chemosensory conveys important information about the quality and nutritional value of food, allowing insects to avoid potentially toxic or unsuitable food and sites [14]. However, in this case, we could not rule out the possibility that the insect was attracted by the odors from sugarcane. Such scenario was not considered in this current study, and this hypothesis needs further investigation. By identifying the

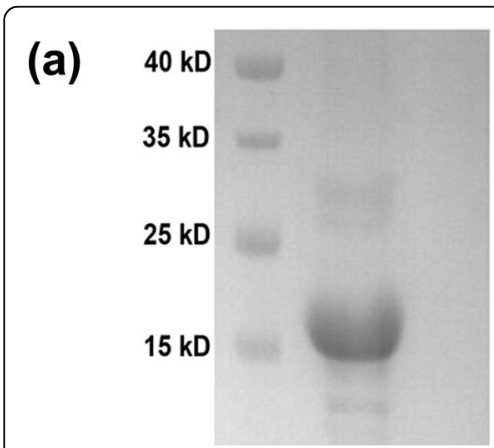

(c)

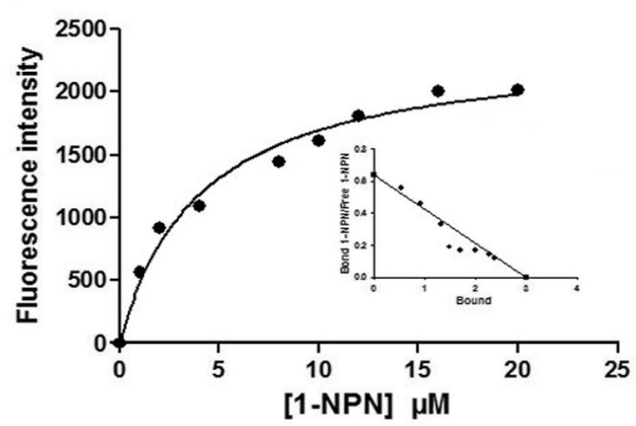

(b)

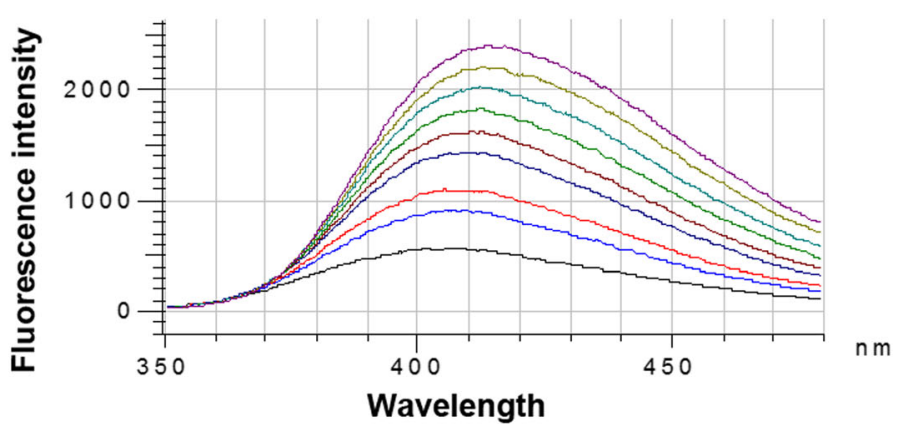

(d)

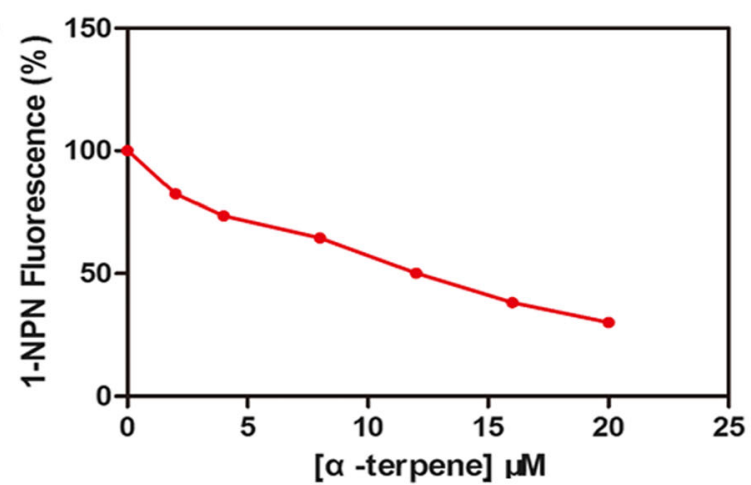

Fig. 6 Binding affinity between CSP and a-pinene by competitive binding assay. a SDS-PAGE of the purified protein of CSP; M: molecular weight marker of 15, 25, 35, and $40 \mathrm{kDa}$. b Binding of 1-NPN to CSP. $4 \mu \mathrm{M}$ of protein in Tris buffer was used here. And aliquots of a $1 \mathrm{mM}$ methanol solution of 1-NPN were added to the protein to final concentrations of 2, 4, 6, 8, 10 12, 14, 16, 18 and $20 \mu \mathrm{M}$ (indicated as black, blue, red, dark blue, grey, light green, dark green, yellow and purple, respectively), and the emission spectra were recorded. c The binding curve and the relative Scatchard plot of binding. $\mathbf{d}$ Competitive binding of a-pinene to CSP. Protein $(4 \mu \mathrm{M})$ was incubated with 1-NPN $(4 \mu \mathrm{M})$ and aliquots of different concentrations of ligand were added. For each set of data, fluorescence values were plotted as percent of that obtained in the absence of competitor 
relevant volatiles, our results could set ground-work for further investigations on the transferring mechanism and provide valuable information for "push" odor. In this study, an expedient approach to identify semiochemicals is to compare the volatile collections from host plants at different physiological conditions [35] by using various techniques, such as solvent extraction [36], solid phase microextraction [37] or headspace collection [38], and among them, the headspace collection is preferred as it could reflect the actual releasing situation and quantities of naturally occurring compounds and it does not cause any mechanical wound on plant tissue [38]. By using different methods, the results might have significant variations in both types and concentrations of these identified volatile compounds [39]. The volatile profiles identified in this study are very similar to those obtained by Ghaniniaet al [40], as many compounds, including ethylhexonol, tetradecane, 1,4-methyl-benzene and pentadecane, were identified in both assays. However, the quantities of volatiles differed between the present study and the previously cited one, probably because of the differences in the collection duration, different strains and different growth stages. Implied by Schlaeger et. al., a complex and diverse range of compounds could be collected and identified, but only a subset of them would likely have semiochemical roles [35]. In particular, based on the results in this study, $\alpha$-pinene may have the ability to repel insects, and were also consistent with results previously reported $[41,42]$. As terpenes are important herbivore-induced plant volatiles involved in direct and indirect plant defense against herbivores [43]. Our study characterized the quantity of $\alpha$-pinene at tilling stage was significantly higher compared with that at seedling stage of rice plant (Table 1), and behavioral assay indeed implied that C.auricilius preferred to choose solvent arm rather than the arm equipped with $\alpha$-pinene, suggesting that $\alpha$-pinene could have the ability to repel C.auricilius and implied its potential role to serve as a "push" component in developing "push and pull" strategy against stem borers. And the mRNA expression levels of many TPS genes showed to be significantly regulated at these two stages (Additional file 3: Figure S1). The differentially expressed TPS genes might contribute to the variations in proportions of $\alpha$-pinene at these two different stages.

Here we show that olfaction is sufficient for an insect to differentiate unpleasant odor [13]. In the meanwhile, the preference shift of insect to food or host plants always accompanied by changes in the peripheral chemosensory system, as insect has developed a highly sophisticated sense of smell based on a variety of specific molecular elements, including odorant binding proteins and CSPs $[44,45]$. By transcriptome analysis, 19 CSPs were identified from adult C.auricilius for the first time, and covered all the CSPs expressed in larvae (13 CSPs in larvae). There is possibility that some of the CSPS could not be identified in this study due to the limit of quality of transcriptome sequencing, assemble or annotation, and expression abundance in the insect body [46]. Analyzing expressions of chemosensory receptors after odorant exposure can help identify ligand-receptor interactions in vivo, as it was discovered that exposure to artificially high concentrations of odorants could lead to reliable alterations in mRNA levels of interacting odorant receptors in mammal and insects [47]. After treated by 1.50 $\mathrm{mg} / \mathrm{ml} \alpha$-pinene, 4 CSPs showed significant variations in larvae C.auricilius, suggesting their roles in detection this chemical. High degree binding affinity between CSP8 and $\alpha$-pinene in vitro was observed by competitive fluorescent binding assay (Fig. 6). The binding between protein and ligand was attributed to the spatial structure of proteins and ligands, especially their specific interactions. The binding affinity established in this study does not necessarily mean the actual binding and activation in the lymph of insect, therefore, other techniques, such as RNA interference and knockout, would be essential to fully confirm such binding and its repelling activity also should be evaluated in the field prior to actual applications. And at the same time, those down-regulated and unchanged CSPs might also have roles and contributed to perception of $\alpha$ pinene, which needs further investigation.

\section{Conclusions}

In this study, the preference shift of Cauricilius to rice plant at certain stage was confirmed, $\alpha$-pinene was identified as a key repellent compound and its repelling activity against C.auricilius was also evaluated by Y-tube olfactometer. The transcript levels of 4 CSPS were found to be differentially regulated after the treatment of $\alpha$-pinene, and good binding affinity was confirmed in vitro by competitive binding assay, which suggested such protein was potentially responsible for the perception of $\alpha$-pinene [48]. Overall, our results could help shed lights on the recognition mechanism of C.auricilius to rice plants and $\alpha$-pinene could serve as an important "push" agent in developing push-pull strategy against C.auricilius and other closely related stem borers [49].

\section{Supplementary information}

Supplementary information accompanies this paper at https://doi.org/10. 1186/s12864-019-6112-4.

Additional file 1: Table S1. The primers used in this study to examine the expression level of terpene synthase genes.

Additional file 2: Table S2. The primers used in this study to examine the expression level of CSPS responding to a-pinene.

Additional file 3: Figure S1. Variations in expression levels of TPS genes at seedling stage and tilling stage of rice plants. The data represented the mean values \pm S.E.M of three replicates ${ }^{* * *}: P<0.001$, ${ }^{* *}: P<0.01$; ${ }^{*}$, $P<0.05$, one-way ANOVA). 


\section{Abbreviations}

1-NPN: N-phenyl-1-naphthylamine; CDS: Coding sequence: CSP: Chemosensory protein; GC: Gas chromatograph; IPTG: Isopropyl-Dthiogalactoside; MS: Mass spectrometer; GRT-PCR: Quantitative real-time PCR; TPSs: Terpene synthases genes

\section{Acknowledgements}

Not applicable.

\section{Authors' contributions}

$X Y$ and GZ conceived and designed the experiment; SS, TW and XZ performed the experiment, QL, PW, YC and XY wrote the manuscript. All the authors have read and approved the final manuscript.

\section{Funding}

The costs of sequencing publication fee was supported by the grants from National Natural Science Foundation of China (No.31701812) and the publication fee was supported by Special expert on pest control of modern agricultural industry technology system on economic grain and oil crop industry of Guangdong Province (No. 2016LM1127).

\section{Availability of data and materials}

Original fastq files are available at NCBI Sequence Read Archive with BioProject reference PRJNA563117.

\section{Ethics approval and consent to participate}

Not applicable.

\section{Consent for publication}

Not applicable.

\section{Competing interests}

The authors declare that they have no competing interests.

\section{Author details}

${ }^{1}$ Key Laboratory of Crop Integrated Pest Management in South China, Ministry of Agriculture, South China Agricultural University, Guangzhou, China. ${ }^{2}$ Key Laboratory of Natural Pesticide and Chemical Biology, Ministry of Education, South China Agricultural University, Guangzhou 510642, China. ${ }^{3}$ College of Agriculture, South China Agricultural University, Guangzhou, China. ${ }^{4}$ Guangdong Province Key Laboratory of Microbial Signals and Disease Control, Integrative Microbiology Research Centre, College of Agriculture, South China Agricultural University, Guangzhou, China.

\section{Received: 2 April 2019 Accepted: 20 September 2019}

\section{Published online: 17 October 2019}

\section{References}

1. Saeed Q, Ahmad F, labal N, Zaka SM. Chemical control of polyphagous pests on their auxiliary hosts can minimize insecticide resistance: a case study of Spodoptera exigua Hübner (Lepidoptera: Noctuidae) in cotton agroecosystem. Ecotoxicol Environ Saf. 2019;171:721-7.

2. Eddleston M, Karalliedde L, Buckley N, Fernando R, Hutchinson G, Isbister G, Konradsen F, Murray D, Piola JC, Senanayake N, et al. Pesticide poisoning in the developing world-a minimum pesticides list. Lancet. 2002;360(9340):1163-7.

3. Yan $\mathrm{H}$, Zeng J, Zhong G. The push-pull strategy for citrus psyllid control. Pest Manag Sci. 2015;71(7):893-6.

4. Kergunteuil A, Dugravot S, Danner H, Van Dam NM, Cortesero AM. Characterizing volatiles and attractiveness of five brassicaceous plants with potential for a 'push-pull' strategy toward the cabbage root fly, Delia radicum. J Chem Ecol. 2015;41(4):330-9.

5. Khan Z, Midega CA, Hooper A, Pickett J. Push-pull: chemical ecology-based integrated pest management technology. J Chem Ecol. 2016;42(7):689-97.

6. Khush GS. What it will take to feed 5.0 billion rice consumers in 2030. Plant Mol Biol. 2005;59(1):1-6.

7. Luo G-H, Li X-H, Zhang Z-C, Liu B-S, Huang S-J, Fang J-C. Cloning of two acetylcholinesterase genes and analysis of point mutations putatively associated with Triazophos resistance in Chilo auricilius (Lepidoptera: Pyralidae). J Econ Entomol. 2015;108(3):1289-97.
8. Khan ZR, Midega CAO, Amudavi DM, Hassanali A, Pickett JA. On-farm evaluation of the 'push-pull' technology for the control of stemborers and striga weed on maize in western Kenya. Field Crop Res. 2008;106(3):224-33.

9. Khan ZR, Pickett JA. The 'push-pull' strategy for stemborer management: a case study in exploiting biodiversity and chemical ecology. Ecol Eng Pest Manage. 2004;67:155-64.

10. Nesbitt BF, Beevor PS, Cork A, Hall DR, David H, Nandagopal V. The female sex pheromone of sugarcane stalk borer, Chilo auricilius identification of four components and field tests. J Chem Ecol. 1986;12(6):1377-88.

11. Jaipal S. Evaluation of the biological control agent (Trichogramma chilonis) against the stalk borer (Chilo auricilius) in sugarcane crops. Ann Appl Biol. 1996;128(s1):102-3.

12. Y-q XU, L-h PENG, J-g LUO, P-w WU, Z-j ZENG. Studies on the control effect of closed forest on Dendrolimus punctatus Walker. Jiangxi Plant Prot. 2007;2:012.

13. Conchou L, Anderson P, Birgersson G. Host plant species differentiation in a polyphagous moth: olfaction is enough. J Chem Ecol. 2017;43(8):794-805.

14. Agrawal AA. Host-range evolution: adaptation and trade-offs in fitness of mites on alternative hosts. Ecology. 2000;81(2):500-8.

15. Biondi A, Zappalà L, Di Mauro A, Tropea Garzia G, Russo A, Desneux N, Siscaro G. Can alternative host plant and prey affect phytophagy and biological control by the zoophytophagous mirid Nesidiocoris tenuis? BioControl. 2016;61 (1):79-90.

16. Perdikis D, Favas C, Lykouressis D, Fantinou A. Ecological relationships between non-cultivated plants and insect predators in agroecosystems: the case of Dittrichia viscosa (Asteraceae) and Macrolophus melanotoma (Hemiptera: Miridae). Acta Oecol. 2007;31(3):299-306.

17. Varma A, Avasthy PN. An artificial diet for the rearing of stalk borer, Chilo auricilius dudg. Experientia. 1973;29(9):1161-2.

18. Silva DB, Weldegergis BT, Van Loon JJA, Bueno VHP. Qualitative and quantitative differences in herbivore-induced plant volatile blends from tomato plants infested by either Tuta absoluta or Bemisia tabaci. J Chem Ecol. 2017:43(1):53-65.

19. Yi X, Qi J, Zhou X, Hu MY, Zhong GH. Differential expression of chemosensory-protein genes in midguts in response to diet of Spodoptera litura. Sci Rep. 2017;7(1):296.

20. Livak KJ, Schmittgen TD. Analysis of relative gene expression data using realtime quantitative PCR and the 2- $\Delta \Delta C T$ method. Methods. 2001;25(4):402-8.

21. Jin S, Zhou X, Gu F, Zhong G, Yi X. Olfactory plasticity: variation in the expression of chemosensory receptors in Bactrocera dorsalis in different physiological states. Front Physiol. 2017;8:672.

22. Vieira FG, Rozas J. Comparative genomics of the odorant-binding and chemosensory protein gene families across the Arthropoda: origin and evolutionary history of the chemosensory system. Genome Biol Evol. 2011;3: 476-90.

23. Bradford MM. A rapid and sensitive method for the quantitation of microgram quantities of protein utilizing the principle of protein-dye binding. Anal Biochem. 1976;72(1-2):248-54.

24. Gu S-H, Zhou J-J, Wang G-R, Zhang Y-J, Guo Y-Y. Sex pheromone recognition and immunolocalization of three pheromone binding proteins in the black cutworm moth Agrotis ipsilon. Insect Biochem Mol Biol. 2013;43(3):237-51.

25. Cao D, Liu Y, Wei J, Liao X, Walker WB, Li J, Wang G. Identification of candidate olfactory genes in Chilo suppressalis by antennal transcriptome analysis. Int J Biol Sci. 2014;10(8):846-60.

26. Renuka P, Madhav MS, Padmakumari AP, Barbadikar KM, Mangrauthia SK, Vijaya Sudhakara Rao K, Marla SS, Ravindra Babu V. RNA-seq of rice yellow stem borer $<$ em $>$ Scirpophaga incertulas $</$ em $>$ reveals molecular insights during four larval developmental stages. G3. 2017;7(9):3031-45.

27. Zhang $Y-N$, Jin J-Y, Jin R, Xia Y-H, Zhou J-J, Deng J-Y, Dong S-L. Differential expression patterns in chemosensory and non-chemosensory tissues of putative chemosensory genes identified by transcriptome analysis of insect pest the purple stem borer Sesamia inferens (Walker). PLoS One. 2013;8(7):e69715.

28. Lou Y, Hua X, Turlings TCJ, Cheng J, Chen X, Ye G. Differences in induced volatile emissions among Rice varieties result in differential attraction and parasitism of Nilaparvata lugens eggs by the parasitoid Anagrus nilaparvatae in the field. J Chem Ecol. 2006;32(11):2375.

29. Santos NA, Teixeira NC, Valim JOS, Almeida EFA, Oliveira MGA, Campos WG. Sulfur fertilization increases defense metabolites and nitrogen but decreases plant resistance against a host-specific insect. Bull Entomol Res. 2017;108(4): 479-86. 
30. Liu X-F, Chen H-H, Li J-K, Zhang R, Turlings TCJ, Chen L. Volatiles released by Chinese liquorice roots mediate host location behaviour by neonate Porphyrophora sophorae (Hemiptera: Margarodidae). Pest Manag Sci. 2016; 72(10):1959-64.

31. Zagrobelny M, Simonsen HT, Olsen CE, Bak S, Møller BL. Volatiles from the burnet moth Zygaena filipendulae (Lepidoptera) and associated flowers, and their involvement in mating communication. Physiol Entomol. 2015; 40(4):284-95.

32. Erb M, Robert CAM. Sequestration of plant secondary metabolites by insect herbivores: molecular mechanisms and ecological consequences. Curr Opin Insect Sci. 2016;14:8-11.

33. Badenes-Perez FR, Gershenzon J, Heckel DG. Insect attraction versus plant defense: young leaves high in Glucosinolates stimulate oviposition by a specialist herbivore despite poor larval survival due to high Saponin content. PLoS One. 2014:9(4):e95766.

34. Dennis EJ, Dobosiewicz M, Jin X, Duvall LB, Hartman PS, Bargmann Cl, Vosshall LB. A natural variant and engineered mutation in a GPCR promote DEET resistance in C. elegans. Nature. 2018;562(7725):119-23.

35. Schlaeger S, Pickett JA, Birkett MA. Prospects for management of whitefly using plant semiochemicals, compared with related pests. Pest Manag Sci. 2018;74(11):2405-11.

36. Rodríguez-Solana R, Salgado JM, Domínguez JM, Cortés-Diéguez S. Comparison of Soxhlet, accelerated solvent and supercritical fluid extraction techniques for volatile (GC-MS and GC/FID) and phenolic compounds (HPLCESI/MS/MS) from Lamiaceae species. Phytochem Anal. 2015;26(1):61-71.

37. Kusano M, Kobayashi M, lizuka Y, Fukushima A, Saito K. Unbiased profiling of volatile organic compounds in the headspace of Allium plants using an intube extraction device. BMC Res Notes. 2016;9(1):133.

38. Vuts J, Woodcock CM, Caulfield JC, Powers SJ, Pickett JA, Birkett MA. Isolation and identification of floral attractants from a nectar plant for the dried bean beetle, Acanthoscelides obtectus (Coleoptera: Chrysomelidae, Bruchinae). Pest Manag Sci. 2018;74(9):2069-75.

39. Cao Y, Li C, Yang H, Li J, Li S, Wang Y, Gao Y. Laboratory and field investigation on the orientation of Frankliniella occidentalis (Thysanoptera: Thripidae) to more suitable host plants driven by volatiles and component analysis of volatiles. Pest Manag Sci. 2019;75(3):598-606.

40. Ghaninia M, Amooghli Tabari M. Olfactory cues explain differential attraction of the striped rice stem borer to different varieties of rice plant. J Appl Entomol. 2016;140(5):376-85.

41. Govindarajan M, Rajeswary M, Hoti SL, Bhattacharyya A, Benelli G. Eugenol, $a$-pinene and $\beta$-caryophyllene from Plectranthus barbatus essential oil as eco-friendly larvicides against malaria, dengue and Japanese encephalitis mosquito vectors. Parasitol Res. 2016;115(2):807-15.

42. Haselton AT, Acevedo A, Kuruvilla J, Werner E, Kiernan J, Dhar P. Repellency of apinene against the house fly, Musca domestica. Phytochemistry. 2015;117:469-75.

43. Gols R, Bullock JM, Dicke M, Bukovinszky T, Harvey JA. Smelling the wood from the trees: non-linear parasitoid responses to volatile attractants produced by wild and cultivated cabbage. J Chem Ecol. 2011;37(8):795.

44. González D, Zhao Q, McMahan C, Velasquez D, Haskins WE, Sponsel V, Cassill A, Renthal R. The major antennal chemosensory protein of red imported fire ant workers. Insect Mol Biol. 2009;18(3):395-404.

45. Carr WES, Gleeson RA, Trapido-Rosenthal HG. The role of perireceptor events in chemosensory processes. Trends Neurosci. 1990;13(6):212-5.

46. Rinker DC, Pitts RJ, Zhou X, Suh E, Rokas A, Zwiebel LJ. Blood meal-induced changes to antennal transcriptome profiles reveal shifts in odor sensitivities in <em>Anopheles gambiae</em>. Proc Natl Acad Sci. 2013;1 10(20):8260-5.

47. Koerte S, Keesey IW, Khallaf MA, Cortés Llorca L, Grosse-Wilde E, Hansson BS, Knaden M. Evaluation of the DREAM technique for a high-throughput deorphanization of chemosensory receptors in drosophila. Front Mol Neurosci. 2018;11:366.

48. Paz Celorio-Mancera M, Wheat CW, Vogel H, Söderlind L, Janz N, Nylin S. Mechanisms of macroevolution: polyphagous plasticity in butterfly larvae revealed by RNA-Seq. Mol Ecol. 2013;22(19):4884-95.

49. Sarles L, Boullis A, Fassotte B, Lognay G, Verhaeghe A, Francis F, Verheggen FJ. Identification of walnut husk (Juglans regia L.) volatiles and the behavioural response of the invasive walnut husk fly, rhagoletis completa cresson. Pest Manag Sci. 2017;73(10):2100-4

\section{Publisher's Note}

Springer Nature remains neutral with regard to jurisdictional claims in published maps and institutional affiliations.

\section{Ready to submit your research? Choose BMC and benefit from:}

- fast, convenient online submission

- thorough peer review by experienced researchers in your field

- rapid publication on acceptance

- support for research data, including large and complex data types

- gold Open Access which fosters wider collaboration and increased citations

- maximum visibility for your research: over $100 \mathrm{M}$ website views per year

At BMC, research is always in progress.

Learn more biomedcentral.com/submissions 